\title{
GAMBARAN KADAR LDL PADA REMAJA OBES DI MINAHASA
}

\author{
${ }^{1}$ Inda V. M. Rawung \\ ${ }^{2}$ Fatimawali \\ ${ }^{3}$ Aaltje E. Manampiring
}

\author{
Bagian Kimia Fakultas Kedokteran Universitas Sam Ratulangi Manado \\ Email: indarawung@gmail.com
}

\begin{abstract}
Obesity is commonly found in Indonesian including elderly, teenagers, and children. Besides genetic factor, there are some other factors that cause obesity inter alia lifestyle with unhealthy food consumption. Foods such as fatty meat contains low density lipoprotein (LDL) cholesterol which might adversely affect our condition since the early age. This was a descriptive study with a cross sectional design conducted at SMK Negeri 2 and 3 in Tondano Minahasa. Sampels were 54 obese teenagers. The results showed that half of the obese students had above normal LDL cholesterol level.
\end{abstract}

Keywords: teenagers, obese, LDL

\begin{abstract}
Abstrak: Obesitas merupakan hal yang sering dijumpai di Indonesia dan mengenai berbagai lapisan usia baik tua, muda, remaja, bahkan usia lanjut. Obesitas terjadi bukan saja terjadi karena faktor genetik, tetapi dapat juga disebabkan antara lain oleh pola hidup daan kebiasaan makan yang tidak sehat. Daging yang berlemak mengandung kolesterol low density lipoprotein (LDL) yang berpengaruh buruk bagi kesehatan bila tidak ditanggulangi sejak usia dini. Penelitian ini menggunakan metode deskriptif dengan desain potong lintang dan dilakukan terhadap remaja obes di SMK Negeri 2 dan 3 di Kabupaten Minahasa. Hasil penelitian menunjukkan bahwa 50\% remaja obes di Kabupaten Minahasa memiliki nilai kadar LDL yang lebih tinggi dari batas normal.
\end{abstract}

Kata kunci: remaja, obes, LDL

Obesitas menjadi masalah di seluruh dunia karena prevalensinya yang meningkat pada orang dewasa dan anak baik di negara maju maupun negara sedang berkembang. Di antara Negara sedang berkembang, jumlah anak usia sekolah (remaja) dengan overweight terbanyak berada di kawasan Asia yaitu $60 \%$ populasi atau sekitar 10,6 juta jiwa. Peningkatan prevalensi obesitas terjadi karena berkurangnya aktivitas fisik dan perubahan pola makan. ${ }^{1}$ Tingkat obesitas terbesar ditemukan di kawasan Amerika dimana 26\% dari orang dewasanya menderita kegemukan sementara tingkat obesitas terendah terdapat di kawasan Asia Tenggara sebanyak 3\%. Penelitian itu juga menunjukkan bahwa diseluruh kawasan dunia, wanita obes lebih banyak dari pria dan ini berbahaya karena meningkatkan risiko menderita diabetes, penyakit kardiovaskular, dan beberapa jenis kanker. Penyakit tidak menular saat ini menyumbang dua pertiga angka kematian di seluruh dunia sehingga WHO memberikan perhatian khusus antara lain dengan menyelenggarakan pertemuan tingkat tinggi untuk membahas peningkatan angka kematian akibat penyakit hati dan jantung, diabetes, serta kanker. Pertemuan The World Health Assembly yang digelar di Jenewa Swis juga melakukan evaluasi perkembangan dari setiap negara dan untuk menentukan langkah selanjutnya. ${ }^{2}$ 
Tingkat kegemukan atau obesitas manusia di Indonesia sejak tahun 1989 terus naik hingga sekarang, baik pada kelompok pria maupun wanita dan kenaikan tingkat obesitas ini terjadi akibat berubahnya pola hidup terutama pola makan. ${ }^{3}$ Remaja merupakan masa transisi anak dan dewasa. Selama remaja, terjadi perubahan hormonal yang mempercepat pertumbuhan. Kebutuhan zat gizi pada remaja meningkat untuk mendukung pertumbuhan fisik. Pola makan pada remaja memengaruhi pertumbuhan dan dapat berdampak pada penyakit kronis di kemudian hari (Dep. Gizi dan Kesehatan Masyarakat, 2007). Ketidakseimbangan antara asupan energi pada remaja dapat menimbulkan masalah gizi, baik berupa masalah gizi lebih maupun gizi kurang. ${ }^{3}$

Obesitas (kegemukan) merupakan salah satu masalah yang ditakuti remaja, khususnya remaja putri. Mereka merasa kehilangan kepercayaan diri ketika memiliki bentuk tubuh yang tidak proporsional seperti memiliki banyak lipatan perut, pinggang, maupun lengan. Obesitas atau kegemukan pada remaja tidak dapat dipandang sebelah mata. Obesitas pada remaja sering menimbulkan risiko kesehatan lainnya yang lebih serius. ${ }^{4}$

Dahulu orang selalu berpikir dua kali sebelum melangkahkan kaki menuju rumah makan di Manado. Pertama, khawatir kalau salah pilih karena nama masakan yang tidak akrab, dan kedua takut kepedasan. Pada hari besar seperti Natal dan Tahun Baru, atau pada hari Sabtu, pasar ramai dengan pengunjung, diserbu pembeli dari luar kota seperti Minahasa Selatan, Manado dan Bitung. Pasar Tomohon dianggap sebagai pasar terbesar dan terlengkap di Sulawesi Utara. Selintas, Pasar Tomohon memang tak jauh beda dengan pasar lainnya di Indonesia. Di bagian depan pasar terdapat pedagang yang menjual segala jenis barang kelontong, sayuran dan rempah-rempah. namun masuk ke dalam pasar, terutama di bagian penjualan daging, ada yang tak lazim disitu bagi pengunjung dari luar Minahasa. Tidak ada penjual daging kambing. Penjual daging sapi juga tidak banyak. Yang terbanyak dijejer di pasar ini ialah daging babi, anjing, ular, kelelawar, dan tikus. Hampir semua daging hewan yang dijual disini belum dikuliti, bahkan masih lengkap dengan kepalanya. Tentu saja pemandangan seperti ini bukan hal yang aneh bagi masyarakat Manado. Daging-daging hewan ini justru menjadi makanan favorit mereka. Meski terdapat daging ayam dan sapi, atau ikan segar, tapi tetap saja kelelawar atau tikus yang dibeli. ${ }^{5}$

Kolesterol yang dibutuhkan secara normal diproduksi sendiri oleh tubuh dalam jumlah yang tepat tetapi bisa meningkat jumlahnya karena makanan ekstern yang berasal dari lemak hewani, telur dan yang disebut sebagai makanan sampah (junk food). Sebagian besar kolesterol dalam darah dibawa oleh protein yang disebut lipoprotein densitas rendah (LDL) yang berpotensi mengakibatkan plak ateroma. ${ }^{4,5}$

Berdasarkan latar belakang di atas peneliti tertarik untuk melakukan penelitian mengenai gambaran kadar LDL pada remaja obes di kabupaten Minahasa.

\section{METODE PENELITIAN}

Jenis penelitian ini menggunakan metode deskriptif dengan desain potong lintang. Penelitian dilakukan di SMK di kabupaten Minahasa. Populasi penelitian ini ialah siswa obes berusia 13-18 tahun di kabupaten Minahasa. Sampel penelitian ialah siswa obes SMK 2 dan SMK 3 di Tondano kabupaten Minahasa.

Pemilihan sampel obes dengan cara pengukuran tinggi badan dan berat badan serta pengambilan darah vena 5cc sampel dalam keadaan puasa 12 jam. Sampel darah diperiksa kadar kolesterol LDL (Low Density Lipoprotein) di laboratorium.

\section{HASIL PENELITIAN}

Dalam penelitian yang dilaksanakan di SMK Negeri 2 dan 3 Tondano pada bulan Agustus 2012-Januari 2013 dilakukan pengukuran lingkar pinggang secara acak terhadap 395 orang siswa di SMK Negeri di Kota Tondano. Diambil 104 siswa remaja obes, kemudian diambil secara acak 54 siswa obes sebagai sampel. 
Tabel 1 memperlihatkan bahwa 4 siswa laki-laki dan 23 siswa perempuan dengan jumlah 27 siswa (50\%) tergolong memiliki kadar LDL melebihi nilai normal sedangkan 6 siswa laki-laki dan 21 siswa perempuan (50\%) tergolong memiliki nilai LDL normal. Dengan demikian dari 54 siswa obes terdapat 27 (50\%) siswa yang kadar nilai LDL- nya lebih dari normal. Dari 54 sampel yang diteliti yaitu 11 siswa laki-laki dan 43 siswa perempuan semuanya memliki lingkar pinggang yang melebihi normal.

Tabel 1. Distribusi frekuensi kadar LDL dan lingkar pinggang

\begin{tabular}{|c|c|c|c|}
\hline \multirow[t]{2}{*}{ Kriteria Diagnostik } & \multicolumn{2}{|c|}{ Jenis Kelamin } & \multirow[t]{2}{*}{ Jumlah } \\
\hline & $\mathrm{L}$ & $\mathrm{P}$ & \\
\hline \multicolumn{4}{|c|}{ Kadar kolesterol LDL } \\
\hline$>160$ & 4 & 23 & 27 (50\%) \\
\hline$<159$ & 6 & 21 & 27 (50\%) \\
\hline \multicolumn{4}{|l|}{ Lingkar pinggang } \\
\hline$>90 \mathrm{~cm}$ & 11 & - & \\
\hline$>80 \mathrm{~cm}$ & - & 43 & 54 (100\%) \\
\hline
\end{tabular}

Keterangan: $\mathrm{L}$ = Laki-laki; $\mathrm{P}$ = Perempuan

Kadar kolesterol LDL:

130-159 = Batas normal tertinggi

160-189 = tinggi

$>190$ = sangat tinggi

\section{BAHASAN}

Dalam 10 tahun terakhir ini, angka prevalensi atau kejadian obesitas di seluruh dunia menunjukkan peningkatan yang signifikan. Saat ini, 1,6 miliar orang dewasa di seluruh dunia mengalami berat badan lebih (overweight), dan sekurangkurangnya 400 juta diantaranya mengalami obesitas. Pada tahun 2015, diperkirakan 2,3 miliar orang dewasa akan mengalami overweight dan 700 juta di antaranya mengalami obesitas. Kejadian obesitas di negara-negara maju seperti di negaranegara Eropa, Amerika, dan Australia telah mencapai tingkatan epidemi. Kejadian ini tidak hanya terjadi di negara-negara maju saja, obesitas di beberapa negara berkembang bahkan telah menjadi masalah kesehatan yang lebih serius. Sebagai contoh, $70 \%$ dan penduduk dewasa Polynesia di Samoa masuk kategori obesitas (WHO, 1998). Pada awalnya, obesitas tidak dianggap sebagai penyakit serius oleh WHO, karena obesitas diasumsikan hanya terdapat pada komunitas masyarakat tertentu yang makmur atau sejahtera saja sehingga perhatian WHO lebih difokuskan pada masalah kurang gizi di negara berkembang. Kenyataan saat angka prevalensi masalah gizi lebih (overnutrition) termasuk obesitas, ternyata lebih banyak terjadi daripada masalah gizi kurang (under-nutrition). ${ }^{6}$

Di Indonesia, angka prevalensi obesitas juga menunjukkan angka yang cukup mengkhawatirkan. Berdasarkan data SUSENAS tahun 2004, prevalensi obesitas pada anak telah mencapai $11 \%$. Berdasarkan data Riset Kesehatan Dasar (Riskesdas) tahun 2007, prevalensi nasional obesitas umum pada penduduk berusia $\geq 15$ tahun adalah 10,3\% terdiri dari laki-laki $13,9 \%$, dan perempuan 23,8\%, sedangkan prevalensi overweight pada anak-anak usia 6-14 tahun pada laki-laki 9,5\% dan pada perempuan 6,4\%. Angka ini hampir sama dengan estimasi WHO sebesar $10 \%$ pada anak usia 5-17 tahun. ${ }^{6}$

Obesitas adalah kelebihan berat badan sebagai akibat dari penimbunan lemak tubuh yang berlebihan. Keadaan ini tentunya berbeda dengan kelebihan berat badan karena penambahan massa otot atau tulang. Sesorang yang obesitas sudah pasti 
kelebihan berat badan, tetapi orang yang kelebihan berat badan belum tentu obesitas. Perempuan dikatakan obes bila lemak dalam tubuhnya lebih dari $27 \%$ berat badan, sedangkan laki-laki disebut obes bila lemak tubuhnya lebih dari 25\% berat badanya. Obesitas tidak hanya ditemukan pada penduduk dewasa, tetapi juga pada anak-anak dan remaja. Obesitas terjadi akibat mengonsumsi kalori lebih banyak dari yang diperlukan oleh tubuh. Faktor utama terjadinya obesitas adalah ketidaksimbangan asupan energi yang diperoleh dengan keluaran energi. Asupan energi tinggi bila konsumsi makanan berlebihan, sedangkan keluaran energi menjadi rendah bila metabolisme tubuh dan aktivitas fisik rendah. ${ }^{7}$

Suatu keadaan yang disebabkan karena adanya kelainan metabolisme lipid yang ditandai dengan peningkatan kadar trigliserida dan kolesterol di dalam darah disebut hiperlipoproteinemia atau hiperlipidemia. Seseorang yang obesitas belum tentu mengalami hiperlipidemia apabila aktifitas fisiknya tinggi dan tidak mengalami gangguan metabolisme lipid, karena penimbunan lemak pada obesitas terjadi dalam jaringan adiposa. Suatu keadaan hiperlipidemia terjadi karena adanya gangguan metabolisme lipid dan terjadi peningkatan kadar lipid di dalam darah akibat diet yang tidak sehat atau mengkonsumsi makanan yang mengandung lemak tinggi. Dalam keadaan ini bisa dilakukan uji kolesterol atau disebut juga panel lipid atau profil lipid yang bertujuan untuk mengukur kadar lemak (lipid) dalam darah. Pemeriksaan profil lemak darah meliputi pemeriksaan: Kolesterol-total, kolesterol-LDL, kolesterol-HDL, dan trigliserida. Pemeriksaan ini memerlukan persiapan puasa mulai 12 jam sebelumnya (tidak makan atau minum, kecuali air putih). ${ }^{8}$

Dari hasil pemeriksaan yang dilaksanakan di Kota Tondano pada bulan Agustus 2012 sampai dengan Januari 2013 didapatkan hasil sebagai berikut: 4 lakilaki dan 23 perempuan dengan jumlah sebanyak 27 siswa (50\%) memiliki kadar
LDL (lemak jahat) lebih dari normal dan 6 laki-laki dan 21 perempuan dengan jumlah 27 siswa (50\%) yang memiliki nilai LDL yang normal. Semua sampel ialah siswa yang sudah mengalami obesitas (LP: lakilaki $>90 \mathrm{~cm}$, perempuan $>80 \mathrm{~cm}$ ).

Hasil penelitian ini mungkin berhubungan dengan faktor-faktor antara lain peningkatan asupan gizi. Penelitian yang dilakukan oleh Kandou ${ }^{9}$ menunjukkan bahwa masyarakat Minahasa termasuk kelompok usia remaja memiliki kebiasaan makan makanan yang mengandung lemak, protein, dan karbohidrat tinggi. Hal ini berkaitan juga dengan kebiasaan tradisi orang Minahasa yang gemar mengadakan pesta bahkan kegiatan-kegiatan sosial kerohanian yang selalu menyajikan konsumsi makanan yang berlebihan.

Tingginya kadar LDL tersebut dapat memengaruhi kesehatan remaja dikemudian hari yaitu berisiko menderita penyakit kardiovaskular, antara lain: penyakit jantung koroner, hipertensi, diabetes, dan stroke. ${ }^{9}$

\section{SIMPULAN}

Dari hasil penelitian dan bahasan dapat disimpulkan bahwa setengah dari siswa obes di SMK Negeri 2 dan 3 Tondano tergolong memiliki kadar kolesterol LDL melebihi nilai normal.

\section{DAFTAR PUSTAKA}

1. Harjana D. Gejala obesitas, penyebab, faktor resiko dan pencegahan. Available from URL: http://gejalapenyakitmu.blogspot.co $\mathrm{m} / 2013 / 07 /$ gejala-obesitaspenyebab-faktor-resiko.html

2. Rahayu RN. Obesitas abdominal, kadar kolesterol LDL dan kolesterol HDL pada pria. Semarang: Program Studi Ilmu Gizi Universitas Diponegoro, 2010.

3. Hasrani H. Kolesterol: perbedaan HDL dan LDL. Bogor 2009. Available from: URL: http://www.cyberflasher.com//medical-room//1285kolesterol.html

4. Suswati. Karya tulis ilmiah kebidanan. Available from: URL: http://karya- 
tulis-ilmiah-kebidanan-

pdf.blogspot.com/2011/09/gambara

n-pengetahuan-remaja-tentang.html

5. Salma. 2009. Hasil kolesterol. Available from: URL

http://majalahkesehatan.com/artihasil-tes-kolesterol-darah-anda/

6. James P. Obesity: A Global Problem. [cited 02 Juni 2011]. Available from: URL:

http://triwitono.staff.ugm.ac.id/inde x.php?option=com_content\&view= article\&id $=78$

7. Supriyono. Indikator lingkar perut. [cited 24 September 2012]. Available from:

URL: http://majalahkesehatan.com/saatny a-mengukur-lingkar-perut/

8. Info Laboratorium Kesehatan. [cited 25 Januari 2012]. Available from: URL:

https://infolaboratoriumkesehatan.w ordpress.com/tag/profil-lipid-kadarlemak-darah/

9. Kandou GD. 2009. Makanan etnik Minahasa dan kejadian penyakit jantung koroner. Available from: URL:

http://jurnalkesmas.ui.ac.id/index .php/kesmas/article/view/200 